\title{
Colonial Education System in Africa: The German Experience in Cameroon 1884-1916
}

\author{
René Ngek Monteh ${ }^{\mathrm{a}}$
}

\begin{abstract}
In early colonial times, European scientists and politicians explained and justified the aggressive and devastating expansion of Europe to nearly every corner of the world. Africans, for example, had been dehumanized, infantilized, and bereft of history. The legacy of this colonial enterprise can still be observed in various activities of the African especially in the domain of education. The German colonial effort only began in 1884 with the scramble for Africa but was short-lived in their stay in Africa. As a result, they implemented their own form of education in their colonies in Africa and that was the case in Cameroon. In this sphere, the German colonial authority realized that they gained strength over colonized nations not only through physical control, but also through mental control. This mental control was carried out through their education system. The German educational goal in Cameroon, like elsewhere in Africa, was to expose Africans to a superior culture with the hope that education will usher the natives into the modern world and will make them more civilized. Captured from this background, this paper, in the first segment, analyze the political objectives of the German educational system in Cameroon with emphasis on their desire to extend overseas culture to the natives. Secondly, the characteristics of this educational system in the domains of school premises, teaching style, curriculum contents, and educational organization are examined. At the end, this paper investigates the difficulties faced and the drastic impact of such education especially in the domain of traditional administration in the study local.
\end{abstract}

Keywords

African, Cameroon, colonial education, western culture

On July 12, 1884, Kings Akwa and Bell signed the Germano-Duala treaty with the German merchants Eduard Schmidt and Johannes Voss, respectively representing the firms Woermann and Jantzen and Thoormählen. In this treaty, these Duala Kings probably abandon their rights of sovereignty, legislation, and the administration of their territory to the above-mentioned firms, making Cameroon a German protectorate (Fanso 1975: 239). From then on, the Germans will administer the territory by touching practically all the domains of life, especially that of education by establishing a foreign educational system. Education in this colonial context is defined as the act of bringing an individual to take and internalize the principles governing community life. The educational system is therefore understood to mean all the institutions involved in the educational function and also the overall organization of school architecture, that is to say, the general courses studies: cycles, fields of study, and orientation (outlets) amongst others. In this paper, we asked ourselves on what were

\footnotetext{
aUniversity of Yaoundé 1, Cameroon

\section{Correspondent Author:}

René Ngek Monteh, HTTC-University of Yaoundé 1, PO Box 47 Yaoundé, Cameroon
} 
the features of the German educational system in Cameroon? In order to bring more clarification in this interrogation, we shall first of all present the objectives of the German educational policy in the Cameroon. Secondly, we shall equally highlight its characteristics. Thirdly, we shall examine the obstacles faced by this educational system and finally the impact of this German education system in the Cameroon.

\section{THE OBJECTIVES OF THE GERMAN EDUCATIONAL POLICY IN CAMEROON}

A few years after the signing of the Germano-Duala treaty, the Germans set up an educational system to achieve various objectives. In this line, some of the objectives amongst others were the extension of colonial authority by missions, the spread of the German language, the search for translators, and exclusion of the Pidgin English language (Eyongetah and Brain 1974: 23).

This extension resulted in the setting up of several missions serving the interests of the Germans. These missions were entrusted with the heavy task of dealing with educational affairs. Some of these missions were: the Protestant or the Basel mission in Bale, located in Douala and in the North-West, which creates stations and employs European missions. This mission was a commercial enterprise with factories. This mission even went so far as to lend money to Cameroonians. As for the Catholic mission installed in Douala and other areas, it was made up of the Pallotine fathers, in which majorities were Germans (Owona 1973: 16-36). They settled inside main land because for them this area was more paying than that of the coast. As for the Baptist mission, they were located in Douala and in the center. They arrived in the territory after the Basel mission but however, created multiple stations in the years prior to German annexation. Their members consisted of natives and school children.
In 1889, the Papacy and the German government agreed on a German Catholic Missionary Society in Cameroon on condition that the head of the mission remained, at all time, a German appointed in consultation with the German imperial government. Such a condition suggested the search for safeguard on political grounds. It was also agreed that the imperial government should have the authority to inspect and monitor Catholic schools. The Propaganda Fide authorized the Pallotine fathers who had a majority of German membership even though the founder was Italian. They were established at Marienberg (1890), Kribi and Edea (1891), Engelberg (1894), Douala (1898), Grand Batanga (1900), Yaounde-Mvolye (1900), Ikassa (1906), Einsieldehen (1907), and Victoria (1908). Initially, they faced demands from the Basel mission not to establish themselves near their existing stations (Basung Gwanfogbe 1995: 63-64). In fact, their arrival ushered in the inter-denominational rivalry in Cameroon which has outlived the colonial period.

In 1904, the apostolic vicariate of the Cameroon was created and was entrusted to the fathers of the Pia societas Missionum. These missions were very important because the German colonial authority saw missionary activity as a civilizing task whose aim was to educate indigenous people and finally to make them subordinate who were industrious and submissive. Hence the famous slogan: "Colonization is the missionary action of the German Minister Solf" (Mballa Owono 1986: 16). In other words, colonization was a work of the missions and it was thanks to this that the government covered all their needs. It is also important to note the presence of the American Presbyterian Mission (APM) who arrived in 1879, whose influence was not neglected. In the northern part of Cameroon especially in Garoua, the German resident commissioner Struntel decided that all Muslims would follow their own religion and attend Muslim cults in the local mosque every Friday. 
In the territory (Douala), especially before 1884, the local languages and Pidgin English language were the most practiced or spoken. The colonial authority took more effective measures in order to facilitate the spread of the German language in Cameroon. In April 1910, a law on education was promulgated and Article II stipulated that, with the exception of German, no other language should be taught or used as a medium of instruction. For a good broadcasting of the German language, they will create school curricula for missionary schools. These curricula will have one objective: to get the mainstream of the population to speak German. The German government went as far as subsidizing the missions to spread the German language and culture. The initial subsidy amounted to 20,000 marks (Ngoh 1987: 446). On the other hand, the propagation of German language was difficult to apply because of Article III of the 1910 Act. This article stipulated that the region or Duala language could be used as a means of instruction in Rio Del Rey, Victoria, Edéa, Buea, and Yabassi. This article III then greatly affected the spread of the German language. In order to fight against the Duala language, the German administration decided to limit the teaching of the Duala dialect since this has become a major problem for spread of German language in the area. In this regard, the German colonial government decided to create a school for agriculture as an attempt to disseminate the German language. To integrate this school, it was necessary to be able to express oneself in German (Madiba 1980: 65). The spread of the German language had become a necessity for the colonizers because their colonial policy was threatened. It was equally necessary to cut off Pidgin English from the natives what still binds them.

When the Germans arrived in Douala (Cameroon), they realized that the population were made up of natives drowned from different ethnic compositions. To them, it was necessary to train elites or translators capable of facilitating communication between the colonizers and the natives in order to rapidly extend their colonial policy. For a good training, the Germans decided to send some distinguished Cameroonians to pursue higher education in Germany so as to become promoters of German language, culture, and good translators. Most of the students sent to Germany came from the South of Cameroon. Among those sent to Germany were: Alfred Bell, Mpondo Akwa, Rudolph Duala Manga Bell, Martin Paul Samba, and Charles Atangana who left as a teacher of Ewondo at the Hamburg Colonial Institute (Mballa Owono 1986: 18). In this sphere, the Germans equally needed a good number of administrative auxiliaries in order to help them in the administration of the territory.

On the other hand, the German wanted to eradicate the Pidgin English language in Cameroon by all cost given that it was the most widely spoken language and the most widely used mode of communication especially around the coast. This Pidgin English language was used by traders, natives, planters, and even civil servants. In 1913, the Governor Karl Ebermeir denounced in a circular the use of Pidgin English words in the German language, in conversations, and even in writings. To further eradicate Pidgin English, the Governor instructed his officials to stop the use of Pidgin English in their daily relation with the natives. In this regard, the government introduced German for all subjects and finally absorbed Pidgin English. They equally gained some administrative staff among Cameroonians speaking in Pidgin English (Owona 1973). This is how Governor Seitz stipulated that no European language except German and no local languages will be taught in schools.

The language policy promoted by the government marked the beginning of a serious crisis concerning the language of instruction in Cameroon schools which persist today. It was also the beginning of a disagreement between the state and the missionary societies. The missions felt that evangelization could 
only be effective through local languages. Some Germans argued that extensive teaching of the German language would lead to linguistic homogeneity of Cameroonians which could be potentially disastrous for colonial rule (Wolfgang 1986: 224). They held that:

[...] the propagation of the German language could become a threat [...] as in a manner one rears a conceited, presumptuous and easily dissatisfied breed, for the natives learn from the Europeans much that is damaging and are tempted, when they speak the language of the Europeans, to place themselves on equal footing. (Wolfgang 1986: 224)

Fear of educated Africans having access to information on anti-colonial doctrines, such as the Simplicissimus ${ }^{1}$ documents published by the German Social Democrats, influenced the shaping of the policy.

The language policy and the absence of mass education tended to perpetuate patterns of domination while exerting psychological pressures on the people. Learning in an alien language inevitably led to inferiority complex and lack self confidence and also introduced elements of psychological domination, as Mannoni argued (Mannoni 1956: 54).

\section{THE CHARACTERISTICS OF THE GERMAN EDUCATIONAL SYSTEM IN CAMEROON}

The most important elements of the German educational system in Cameroon are, among others, the language of instruction, subjects taught, and the different levels or cycle of study.

The most striking feature of German educational policy in terms of pedagogy was the language of instruction. In public schools, German language predominated but its preponderance was exclusive during the beginning. A German instructor by name Christaller set himself the goal of learning the Duala language first in order to prepare to his pupils a textbook manual for the teaching of the German grammar. Since the duration of the primary course was not sufficient enough to acquire a good mastery of German language, two additional courses were created for the purpose of improvement. In this connection, the German administration states that the use of "Pidgin" by civil servants was a "national crime" and obliges them to use only German in their dealings with the people (Madiba 1980: 67).

On the other hand, in private schools, the situation was different. Here, the vernacular (Duala) language was credited because Pastor Alfred Saker had already translated the Bible into Duala language since 1872 and had the necessary manuals in Duala before the German arrival in Cameroon in 1884 (Mveng 1984: 113). Alfred Saker's aim was to learn to the students how to write, to read the Bible and how to calculate in their own language not fully agreed by the various missions. The American Presbyterian Mission provided its teaching in the local language for three years at the primary level. The German used this method only for religious courses at the complementary level. The Baptist mission, for its part, devoted the first three years of a six-year study cycle in the learning of mainly the Duala and the other three years exclusively for study of German. The Swiss German mission taught only the official German curriculum in its schools. The Catholic mission on their own used the Duala language in the first classes and German in the more advanced classes (Mveng 1984: 113). As such, German was the language of the general education.

However, following this disharmony observed in different schools, the imperial government commissioned Seitz as colonial Governor in Cameroon to convene a conference on the education in Douala in 1907. In this regard, the first official program for the Cameroon schools was drawn up, consisting between six and 10 hours of compulsory German-language education at the advanced stages of primary school. This trend was confirmed by the decree of April 25, 1910 signed by the German 
Governor, who adopted the official program drawn up in 1907. This school law gave a prominent place to the use of German in schools while admitting that the local language "Duala" should be replaced with the authorization language of the Governor (Mballa Owono 1986: 446). In short, it must be said that German was not the only language of instruction which had served the German educational system in the Cameroon because, besides it, other languages existed like Duala and Pidgin English.

The curriculum contents (subjects taught) in government primary schools focus primarily on subjects summarized in following Table 1 .

As the table below shows, during the first and second years, students were taught reading, writing, drawing, songs, patriotic poems, geometry, technical and agricultural which were taught at the Buea State Technical School and the Victoria Agricultural School. However, the German language becomes the main instructing language from the third year onwards in line with the application of the School Law of 1910. In addition, the advent on the teaching of technical and agricultural programs was part of the German government's concern to train future staffs or collaborators who will serve them in their different domains. It should equally be noted that the training was divided into study programs.

\section{The Program of Studies}

Primarily in this system, we had three programs of studies which were: annual, weekly, and daily program but these programs change from private to public schools.

The public primary course was initially restricted to three years until 1897, and then extended to four years in 1903-1904. Two years later, a sixth year was created called "improvement". Here the author of the Colonial Bulletin states that the timetable for the sixth class corresponds to that of primary schools in Germany. In the private sector, the Basel mission provides training for the two cycles of three years programs each. For the Baptist mission, after the two years for each cycle, a third cycle of four years was added to the school program for the training of the boys' instructors in Douala in 1903-1904. This cycle was then spread over eight years constituting a complete training program (Atangana 1996: 66). In the primary cycle, the academic year in the private as well as the public coincided with the calendar year and was spread over 12 months. Two breaks at Christmas and Easter compensated for the absence of a long vacation. The end of the year is subject to a date of pastoral festival that occurs between March and May. As for the weekly and daily program, the official school in Douala in 1899 used a rotating system which permitted each group of students to receive between 10 to 15 hours weekly (morning or afternoon the classes where to follow). The schedule increased in 1902-1903 from $10 \mathrm{~h}$ to $21 \mathrm{~h}$, then from $24 \mathrm{~h}$ to $33 \mathrm{~h}$ the following year (Atangana 1996: 66).

The situation in private schools was different. The students of the Bale mission for example, in 1896-1897 went to school but in the afternoon. According to the socio-economic considerations, they were given the opportunity to work first at home before coming to school. The Catholic mission provided 20 hours of instruction per week for two hours in the morning and two hours in the afternoon contrary with the Baptist mission who had the classes twice a day (Santerre and Mercier-Tremblay 1982: 437-453).

\section{Attendance and Educational Contribution}

Majority of the administrative reports conclude that general attendance is good. However, the assertion provided by the various missions remains doubtful and contradicting especially where they talk of irregular (1898-1899) and even very irregular (1912-1915) frequentation. The decree of 1910, which instituted a certain compulsory education for registered pupils, recognizes the extent of absenteeism in the classes. On the other hand, there seems to be no difficulty in recruiting. The official school in Douala was to reject 
Table 1. Weekly Schedule of the German Colonial School

\begin{tabular}{|c|c|c|c|c|c|}
\hline Discipline & Classe 1 st year & 2ed year & 3rd year & 4 th year & 5 th year \\
\hline Allemand & $2 \mathrm{~h}$ & $3 \mathrm{~h}$ & $4 \mathrm{~h}$ & $4 \mathrm{~h}$ & $4 \mathrm{~h}$ \\
\hline Observation & $2 \mathrm{~h}$ & $2 \mathrm{~h}$ & $2 \mathrm{~h}$ & & \\
\hline Calcul & $2 \mathrm{~h}$ & $3 \mathrm{~h}$ & $3 \mathrm{~h}$ & $3 \mathrm{~h}$ & $3 \mathrm{~h}$ \\
\hline Géographie & & & $1 \mathrm{~h}$ & $1 \mathrm{~h}$ & $1 \mathrm{~h}$ \\
\hline Histoire & & & & $1 \mathrm{~h}$ & $1 \mathrm{~h}$ \\
\hline Sciences naturelles & & & & $1 \mathrm{~h}$ & $1 \mathrm{~h}$ \\
\hline Total & $6 \mathrm{~h}$ & $8 \mathrm{~h}$ & $10 \mathrm{~h}$ & $10 \mathrm{~h}$ & $10 \mathrm{~h}$ \\
\hline
\end{tabular}

Note: Source: (Mballa Owono 1986).

candidates from 1896 who were less than 10 years after the American Presbyterian Mission, pointing out that among these students, many escaped from their parents especially in the Boulou region who love going to school (Santerre and Mercier-Tremblay 1982: 437-453).

Contrary with that in the North, half a century later, no gift or material benefit at Christmas was responsible for this infatuation. On the contrary, very early missions imposed on their pupils various small works such as gardeners, cooks, or sappers to cover the cost of school materials and obliged them to pay. This is the case in the Presbyterian mission, where small school children were forced to work; this was to show to them that school is worth and that it is not a place to waste time. Easy recruitment and irregular attendance are therefore not excluded and are also explained in the same way by the attractiveness of novelty and the desire for knowledge to which the European school responds (Njeuma 1989: 146).

\section{Boarding and Vocational Schools}

A large proportion of students from missions schools were interns. Out of 1,113 children in 1905-1906, the Presbyterian mission counts 800 interns. Catholic and Protestant missions have many boarding schools where they welcome especially the best students of the environment and especially the girls. The girls' proposal remains weak in official education. They were redoubled to a few units at Douala school until the creation of a girl's class in 1903. The official girls' school was abandoned in Douala in 1897 to the hands of the Bale mission. The government for the institution of girls relied on the missions, certainly because she did not hope anything on her for the administrative services (Santerre and Mercier-Tremblay 1982: 450).

The missions found more advantages for girls for the sake of instituting Christian homes. During the German times, the percentage of female attendance in schools was never more than $20 \%$. Out of the 22,151 students in missions schools in 1909-1910, there were 2,268 girls, which placed the rate of women in private education at $10.2 \%$. The low female enrollment rate at that time depended largely on the general status of women in Cameroon and on their status in their various families of origins. A Catholic father noted that experience has shown in the African context that girls do not have as much desire to learn as boys. Thus, for the girls, the missions have special programs in which there are sewing, embroidery, and household work. Courses are introduced alongside general vernacular education (Njeuma 1989: 145). Very rare are those who go beyond the stage of the first cycle to undertake the study of German and possibly even to the complementary cycle. 


\section{Complementary Level}

There is high restriction on admission number at this complementary level. If one ignores the aborted attempt of 1906, public education counts only two in 1912-1913. The Bale mission still maintained 10 establishments of this type in 1903-1904 and trained 455 of its 5,025. It had already created a higher school at Bonaberi in 1894 and Lebéthal in 1899 and the following year three schools for boys and two German schools. The Catholic and Presbyterian missions were not exceptions in the establishment of seminaries or similar improvement schools (Njeuma 1989: 145).

\section{Agricultural and Technical Education}

Far from being neglected, technical education in all proportion was taken seriously by the various educators during the German reign. In 1910, a school for agriculture in Victoria and an official technical school in Buea appeared under the sponsorship of the German government (Santerre and Mercier-Tremblay 1982: 451). This creation was intended to provide to the administration, the training of technical staffs, which were regularly sent in small number to acquire practical training in Europe. Equally in this field, the missions established remarkable industries amongst others: the Douala printing press created by the Baptist mission, the important carpentry workshop of the Bale mission, and the Catholic teaching centers in Douala and Yaoundé. In Elat (Ebolowa), in the Boulou region, technical and artisanal activities under the American mission operated in the domains of carpentry and tailoring shops enormously assisted a good number of young people who needed the training (Mveng 1984: 231).

Both an oral and a written examination sanctioned the completion of the initial studies. Given the relative absence of accidents among official candidates and the large number of receipts among private-education candidates, the level of such candidates was not excessively high. The lack of German training could normally have led to a considerable desecration. However, it is necessary to cease from judging these tests with the demands of today. Above all, the teaching body was composed of European teachers assisted by natives, to make suitable results. In mission schools, it was usually consisted only of local monitors whose level of training and the colonizer's language were not adequate enough for the first time to facilitate the task (Stoecker 1986: 224).

The opportunities for the beneficiaries of such education were generally limited to a few private enterprises, where the various apprentices sometimes were found employed at missions. The missions at times retained the best pupils for catechists or monitors, and the colonial administration itself took over most of the graduates of its own schools. Thus, in 1909-1910, the 14 students who received the final examination passed directly into the service of the colonial government. The same fate was reserved for the 27 admitted in the following year (Stoecker 1986: 224).

\section{THE OBSTACLES FACED IN THE ESTABLISHMENT OF THE GERMAN EDUCATIONAL SYSTEM}

The German colonial administrators faced many difficulties in the implementation of their educational system in Cameroon. These difficulties vary from physical to socio-cultural features.

\section{Physical Constraints}

On the physical limitation, the German teachers faced in Cameroon the problem of relief and climate in which they were not accustomed. For example, in the northern Cameroon, they encountered severe climatic conditions, including the great dry season, which, when it reaches its peak, hinders the smooth running of academic activities. This permitted the population to go for other activities such as fishing and hunting 
likely to sustain their family. As a result, the school was perceived as an unnecessary waste of time and less profitable and less vital in the daily activities of the people (Altbach and Kelly 1978: 46).

In the southern part of the country, the physical environment and the climatic conditions also had a great impact on the progress of school activities. Access was not easy at that time in dense forest area because it was difficult to find tracks to reach all the corners and those that existed were very impracticable especially during the heavy rainy season ranging from the month of early April to mid October. The forest zone has been an obstacle both for the German educational system and for other colonial activities. This explains why the first mission of exploration in the Cameroon hinterlands of October 1887 did not succeed until later dates. In the grassfields, the hilly nature of the terrain coupled with rivers and rapid made it difficult for the German educational system to gain more stands (Neil 1966: 26). Despite these physical challenges, the German administration through local authorities was able to set the start in their educational system.

\section{Socio-Cultural Constraints}

In setting up their administration in general and that of their educational system in particular, the Germans faced the endogenous realities of Cameroon, especially in the domain of culture. From one ethnic group to another, the Germans were confronted with the habits and customs described as barbarians that represented a hindrance for the implementation of their educational policy.

The confrontation between the Bakweri of Buea and the colonial administration through the missions stem from the accusation of two Bakweri women of having killed a man by sorcery. Then, according to tradition, these women had to swallow poison "sasswood"; if they vomited it, then they would be exonerated but otherwise convicted what happened. A missionary from Bale presented the report to the
Victoria station about the incident in which Von Gravenreuth reacted by sending soldiers to punish the Bakweri (Ngoh 1987: 56). Thus, it emerges here that the Biblical ideals carried by the missionaries did not rhyme with such local practices.

Moreover, in the Beti region of Cameroon (part of the present days centre, east and south regions), the missionaries were confronted with the sacrifice of wife of chief to the death of their husband, whom they find odious. In order to convey the recommendations of the Bible, the missionaries thus encountered several frictions. Still in the Beti region and in most ethnic groups in Cameroon, most missions especially the Catholic doctrine encountered the practice of polygamy but pleaded for monogamy. The German administration was not officially opposed to polygamy but rather instituted a tax on it. The German authorities tried to control girls' early marriages described as "girls' trade" (Njeuma 1989: 150). Hence several traditional practices were abolished, such as the Sso among others coupled with several reasons forwarded to justify this eradication. One of them revealed in 1901 that a young Christian was struck by a Sso armed with a machete (according to a German missionary) and this would have been at the origin of the abolition of the rite (Njeuma 1989: 147).

In the northern sector, the constraint to the implementation of the German educational system in Cameroon was more of a religious order masked here by Islam. In 1906, while opening a school in Garoua, the Muslim populations manifested their discontent. Confronted with this, Struntel decided that Muslims would follow their own religion and that they would attend Muslim cults at the local mosque every Friday. The difficulties encountered by the Germans in this part of Cameroon reflected the socio-cultural realities of the area (Rudin 1938: 356). This was further explained by the priority given by the parents to pastoral activities at the detriment of institutionalized school set up by the missionaries. 


\section{THE IMPACT OF THE GERMAN EDUCATIONAL SYSTEM IN CAMEROON}

The establishment of academic institutions in Cameroon by the Germans had a series of effects on this multi-faceted society. This impact is discussed in the domains of: training of the elites, the awakening of a nationalistic feeling, the phenomenon of acculturation, and the cultural inheritance.

\section{Training of the Elites}

When the Germans arrived in Cameroon, they found companies run by chiefs who had not had a formal academic training except those established by the botanical missions in 1844. Some years after the signing of the Germano-Duala treaty, the German colonial administration with the Christian missions took the educational system with the main reason to train and empower the elites. In this sphere, many were educated as they were taught on how to read, write, count and they were equally initiated to Biblical values and so on. This education acquired put them already in a position of intellectuals compared to those of the regions that had not yet known the advent of the missions. With this instruction, especially some of them such as Alfred Bell and Rudolph Duala Manga Bell just to name a few, were able to continue their studies in Germany (Ngoh 1987: 54). These Cameroonians were able to deliberate and interfere with the situation prevailing in their country. Above all, they were able to influence the colonial administration on the living conditions and the humanizing treatments of their people. However, the German educational system trained and educated people in Cameroon, who constituted the elite of the territory in one way or another. Some elites such as Martin Paul Samba and Charles Atangana who occupied important and prestigious positions of responsibility were able to work in collaboration with the German administration though the main objective of their task was to promote colonial policy within the territory. In all, the extension of schooling by Germans to Cameroon has sufficiently equipped intellectually the "Cameroonians" in their eventual mode of reasoning combined with the understanding of the situation in which they were (Mbassi 1973: 136). In the capacity to work in collaboration with foreigners and in the ability to decide for you, it is then referred to as this colonial school carries within itself the germs of its own destruction.

\section{The Awakening of a Nationalistic Feeling}

As mentioned above, colonization carried within itself the germs of its own destruction. Indeed, the institution of the school in Cameroon contributed unwittingly to a sense of self-affirmation as well as an individual, a people, and a territorial entity. The missions promulgated the ideals of equality and justice of equity between human beings who are all children of God. Contrary with this, the people of Cameroon were subjected to various offers on their own territory. On the other hand, with the advent of schools, the unworthy Cameroonians were seen on equal footing as their colonial administration because they spoke the same language and worked collaboratively. Some of them had the privilege of going to Germany to continue their studies and become elites such as Charles Atangana who even taught Ewondo to the Germans (Ngoh 1987: 54). Besides all these, it became relevant for those elites especially the Duala Kings to multiply this nationalistic doctrine to the people living in the hinterland of Cameroon in order to get rid of the German colonial system.

In fact, in order to finish with the rigid system imposed by the Germans, Rudolph Duala Manga Bell and Martin Paul Samba made an alliance. They were equally supported by King Adola of Grand Batanga, Edande Mbida, and Ngosodin. We see in this reaction an enterprise of self-assertion as an individual and as separate entities. It should be noted that, before the advent of this nationalist spirit advocated by these 
different peoples, relationship that characterized the scene by then was only commercial relations (Ngoh 1987: 66). However, the advent of the German educational system coupled with the harsh colonial system of administration worked in favour of a nationalist feeling to the people of Cameroon.

\section{The Phenomenon of Acculturation}

The encounter between two cultures hardly operates in total cohesion, and this is because one will seem to dominate the other. The case of German and Cameroon did not escape this reality; all the more it was a relationship of subjugation with the German administration. Worse still, the advent of new forms of schools led by the missionaries and under the auspices of the German colonial administration brought most of the endogenous practices to an end. In fact, the promotion of the German language as a means of teaching and communication, contributed adversely in the promotion of the local languages. The Bismarck language presented a promising future of learners especially to the administration in place to the detriment of the endogenous languages (Austen 1977). This is quite noticed where the ability to speak foreign languages offers to nationals a considerable opportunity both at national and international domains.

The German educational system has also been an inhibiting factor to the authority and socialization of the leader in societies. This has made chieftaincy no longer elitist or at least an insider affair. At this moment, it is important to note that the person who is literate, or who most have passed through the school was eligible to the throne. Thus, the essence of the leader's value was relegated to selfish and opportunistic interests. It is from this period that some chiefs such as Martin Paul Samba and Charles Atangana began to be challenged by the indigenous people of the said localities.

\section{Colonial Inheritance}

Inheritance may be considered to be the aggregate of property transferred by succession. It is a matter for us to examine this legacy of the German administration in the field of education. These academic infrastructural institutions were principally established by the missionary societies on the territory. In fact, the Basel mission belts several schools in Douala, Buea, Victoria, Eseka, and Foumban. The American Presbyterian Mission (APM) created several schools, among others the Ebolowa in 1895, Lodolof in 1897, Elat in 1901, and Melet Foulassi in 1916 just to name a few. On the other hand, the Catholic mission of the Pallotine fathers founded Bojongo, Sassé, Dschang, Bamenda, and Bota during the German period (Basung Gwanfogbe 1995: 65). On their part, the German left several educated elites and institutions in the territory. The first indigenous pastor was Eduma Musambani. The German Baptist mission consecrated its first worthy shepherd in the person of Lotin Same. Several worthy teachers were formed. The German language was restored as a linguistic heritage on the territory.

The missions have built up a good number of school infrastructures and with time, a good number of indigenes were found learned thanks to the training they obtained in these schools. The Basel mission being the most domineering mission during the German reign equally saw other missions such as the Catholic, the Baptist, and American Presbyterian missions all working for the same academic purpose. Table 2 below illustrates some of the realizations by these missions in the domain of academic.

\section{CONCLUSIONS}

At the end of the analysis, it would not be an overstatement to say that the German colonial educational system especially through missions as discussed in this paper had impacted the life style of the people of Cameroon. It is clear that the Germans had set up a policy of extending their colonial authority by the missionaries, which encouraged the 
Table 2. German Colonial Academic Legacy

\begin{tabular}{lllll}
\hline Foundations & Years & Schools & Indigenous instructors & Pupils (male \& female) \\
\hline Marienberg & 1890 & 20 & 21 & 74148 \\
Kribi & 1891 & 12 & 12 & 78060 \\
Edéa & 1891 & 32 & 34 & 3,508117 \\
Engelberg & 1894 & 5 & 5 & 23568 \\
Duala & 1898 & 24 & 30 & 1,907301 \\
Grand-Batanga & 1900 & 7 & 9 & 40537 \\
Yaoundé (Mvolyé) & 1901 & 34 & 41 & 5,439260 \\
Ikassa & 1906 & 12 & 12 & 54331 \\
Einsiedeln & 1907 & 5 & 3 & 37515 \\
Victoria & 1908 & 15 & 16 & $?$ \\
Ngovayang & 1909 & 17 & 17 & 1,30615 \\
Dschang & 1910 & 8 & 8 & 1,124180 \\
Ossing & 1912 & 13 & 12 & 430 \\
Minlaba & 1912 & 1 & 3 & 1,36526 \\
Deido & 1913 & 2 & $?$ & 260 \\
Total & & 204 & 223 & 19,576 \\
\hline
\end{tabular}

Notes: Source: Kaiserlichen Statistischen Amte: Statistisches Jahrbuch für das Deutsche Reich 1910-1931.

Table 2 above gives us a brief view with an appreciable record scored by missions in line with modern education during the German colonial period. It is also remarkable that most of the early mission schools were found but at the coastal areas and this explains the value recorded in terms of infrastructure and attendance.

expansion of the German language with the construction of schools on the territory for the most part done by missions. From the beginning, the German colonial authorities have main objective to have the entire control of the territory they named Cameroon. As time goes, the idea of eradicating all what is not German or which could play against their colonial regime became vital. It is in this sphere that the German administration decided to put an end to the existing commercial Pidgin English language that had existed in this area long ago thanks to the Portuguese. As if that is not enough, the local Duala language did not properly work in public places such as in markets, administrative services, and schools. This was a result of some decrees enacted and ratified by the German colonial authorities as time goes. Nevertheless, this colonial educational system has had an enormous impact on the Cameroonians insofar as they attended these schools. This educational system during the German reign accelerated elite formation, a nationalist spirit, and the hope to belong to the same fatherland. This was because the German colonialist was the first to bring all Cameroonians under a single administrative unit or entity. However, despite the hurtful effects of the German colonial system especially in the domain of education, this went long a way in the acculturation and equally participated in the awakening of many Cameroonians especially the coastal chiefs in their territory.

\section{Note}

1. Simplicissimus was a satirical newspaper rather resembling the French, Le Canard enchaine.

\section{References}

Altbach, P. G. and G. P. Kelly, eds. 1978. Education and Colonialism. New York: Longmans. 
Atangana, E. 1996. Cent ans d'éducation scolaire au Cameroun réflexion sur la nature, les moyens et les objectifs de l'entreprise (1885 à nos jours) [One Hundred Years of School Education in Cameroon Reflection on the Nature, Means and Objectives of the Company (1885 to Present Day)]. Paris: Édition L'Harmattan.

Austen, R. 1977. "Douala versus Germans in Cameroon: Economic Dimensions of a Political Conflict." Revue D'Histoire D'Outre Mer 64(237):477-497.

Basung Gwanfogbe, M. 1995. "Changing Regimes and the Development of Education in Cameroon 1886-1966 (With Special Reference to the Basel Mission)." $\mathrm{PhD}$ thesis, Department of History, Humanities and Philosophy/Department of International and Comparative Education, University of London Institute of Education.

Eyongetah, T. and R. Brain. 1974. A History of Cameroon. London: Longmans.

Fanso, V. G. 1975. "Background to the Annexation of Cameroon, 1875-1885.” ABBIA 29-30:231-280.

Madiba, E. 1980. Colonisation et Évangélisation en Afrique: L'Heritage Scolaire du Cameroun (Colonization and Evangelization in Africa: The School Legacy of Cameroon). Bern: Editions Peter Lang.

Mannoni, O. 1956. Prospero and Caliban: The Psychology of Colonisation. London: Mathuen.

Mballa Owono, R. 1986. L'école Coloniale au Cameroun: approche historico-sociologique (The Colonial School in Cameroon: Historico-Sociological Approach). Yaoundé: Edition de l'imprimerie Nationale.

Mbassi, J. 1973. 'L'œuvre culturelle allemande au Cameroun 1884-1914” (German Cultural Work in Cameroon 1884-1914). Postgraduate doctoral thesis, Université de Paris III.

Mveng, E. 1984. Histoire du Cameroun (History of Cameroon). Vol. 1. Yaoundé: CEPER.
Neil, S. 1966. Colonialism and Christian Missions. London: Butterworth Press.

Ngoh, V. J. 1987. Cameroon, 1884-1985: A Hundred Years of History. Yaoundé: Navi-Group Publications.

Njeuma, M. Z., ed. 1989. Introduction to the History of Cameroon: Nineteenth and Twentieth Centuries. New York: St. Martin's Press.

Owona, A. 1973. "La naissance du Cameroun (1884-1914)" [The Birth of Cameroon (1884-1914)]. Cahiers d'Études Africaines 49:16-36.

Rudin, H. 1938. Germans in the Cameroons 1884-1914: A Case Study in Modern Imperialism. New Haven: Yale University Press.

Santerre, R. and C. Mercier-Tremblay. 1982. La quête du savoir: essais pour une anthropologie de l'éducation camerounaise (The Quest for Knowledge: Essays for an Anthropology of Cameroonian Education). Montréal: Les presses de l'Université de Montréal.

Stoecker, H., ed. 1986. German Imperialism in Africa: From the Beginning Until the Second World War. Translated by B. Zöllner. London: Hurst Publishers.

Wolfgang, H. 1986. "Education Policy." In German Imperialism in Africa: From the Beginning Until the Second World War, edited by H. Stoecker. New Jersey: Hurst and Company.

\section{Bio}

René Ngek Monteh, Ph.D. in Political History and International Relations, currently a senior lecturer in the Department of History, the Higher Teacher Training College (ENS) of the University of Yaoundé 1, Cameroon; research fields: conflict and peace studies. 